University of Nebraska - Lincoln

DigitalCommons@University of Nebraska - Lincoln

\title{
Physiological host range of Ceratapion basicorne, a prospective biological control agent of Centaurea solstitialis (Asteraceae)
}

Lincoln Smith

USDA-ARS

Follow this and additional works at: https://digitalcommons.unl.edu/usdaarsfacpub

Part of the Agricultural Science Commons

Smith, Lincoln, "Physiological host range of Ceratapion basicorne, a prospective biological control agent of Centaurea solstitialis (Asteraceae)" (2007). Publications from USDA-ARS / UNL Faculty. 379. https://digitalcommons.unl.edu/usdaarsfacpub/379

This Article is brought to you for free and open access by the U.S. Department of Agriculture: Agricultural Research Service, Lincoln, Nebraska at DigitalCommons@University of Nebraska - Lincoln. It has been accepted for inclusion in Publications from USDA-ARS / UNL Faculty by an authorized administrator of DigitalCommons@University of Nebraska - Lincoln. 


\title{
Physiological host range of Ceratapion basicorne, a prospective biological control agent of Centaurea solstitialis (Asteraceae)
}

\author{
Lincoln Smith * \\ USDA-ARS Western Regional Research Center, 800 Buchanan Street, Albany, CA 94710, USA
}

Received 3 November 2006; accepted 18 December 2006

Available online 29 December 2006

\begin{abstract}
Ceratapion basicorne (Coleoptera: Apionidae) is a weevil native to Europe and western Asia that is being evaluated as a prospective classical biological control agent of Centaurea solstitialis (yellow starthistle) in the United States. Host plant specificity of the insect was evaluated in no-choice oviposition experiments. Feeding on leaf tissue by adult females was highly correlated to oviposition rate, both of which occurred primarily on plants in the tribe Cardueae, and especially those in the monophyletic subtribe Centaureinae. The highest rates of larval development occurred on Ce. solstitialis and Centaurea cyanus (bachelor's button, garden cornflower), and there was significant development on Centaurea melitensis (Napa starthistle, tocalote), Cnicus benedictus (blessed thistle), Carthamus tinctorius (safflower), and Crupina vulgaris (common crupina). All the plants that supported some larval development are within a monophyletic clade within the Centaureinae. No native North American plants appear to be at risk of significant damage by this insect. Additional testing of safflower and bachelor's button under choice conditions should complement these results to help determine the degree to which these plants are at risk.
\end{abstract}

(c) 2006 Elsevier Inc. All rights reserved.

Keywords: Host plant specificity; Biological control; Weed; Invasive plant; Risk assessment

\section{Introduction}

\subsection{Weed distribution, ecology, and impact}

Yellow starthistle (Centaurea solstitialis L.) is an invasive alien weed that was accidentally introduced into California over 130 years ago, primarily by importation of contaminated alfalfa seed (Maddox et al., 1985; Gerlach, 1997a,b). The weed infests about eight million hectares in the western US and Canada (Duncan, 2001; Pitcairn et al., 2006). Infestations have been reported in 23 states, with the largest populations in the states of California, Idaho, Oregon, and Washington (Maddox et al., 1985; Sheley et al., 1999). It is considered the most common weed in California, and it is continuing to spread and threaten states to the east (Pitcairn et al., 2006). The weed is designated as noxious in 11 western states and two Canadian provinces (Skinner et al., 2000).

\footnotetext{
* Fax: +1 5105595737.

E-mail address: 1smith@pw.usda.gov
}

Yellow starthistle is highly invasive in grassland habitats and displaces desirable plants in both natural and grazing areas. Spiny flowerheads interfere with grazing animals and human recreation, and the plants displace desirable vegetation and deplete soil moisture. Consumption of yellow starthistle by horses causes a fatal syndrome known as "chewing disease" or nigropallidal encephalomalacia (Cordy, 1978). Total economic benefits for controlling yellow starthistle in California have been estimated to be between $\$ 40$ million and $\$ 1.4$ billion, depending on assumptions (Jetter et al., 2003). Environmental benefits due to reduced use of herbicides, increased recreation and increased biodiversity have not been estimated, nor have any benefits to nearby states.

Yellow starthistle is an herbaceous winter annual plant native to southern Europe and the Near East (Maddox, 1981), occurring from Spain to Iran (Wagenitz, 1975; Dostál, 1976; Rechinger, 1980). The geographic center of origin may be in Turkey or Greece, based on the number of subspecies occurring in these regions (Wagenitz, 1975; Dostál, 1976). Although the plants in the western USA are genetically 
diverse, there is no evidence of genetically distinct subpopulations occurring there (Roché, 1965; Sheley et al., 1983a,b; Schumacher et al., 1982; Sun, 1997). The plant is well adapted to a Mediterranean climate (dry summers and wet winters) and can tolerate winter snow. In California, seeds germinate mainly in early winter, rosettes grow slowly until spring, then the plants "bolt" and bloom until they die from desiccation or frost (Pitcairn et al., 1999a; Sheley et al., 1999). Some seeds are released during the summer as individual capitula (flower heads) mature while others are retained until the capitula disintegrate during winter. Seeds falling in summer soon become dormant and require cooler temperatures before germinating, usually soon after the start of winter rains. Seeds buried in soil can remain viable for several years and will germinate after exposure to light when the soil is disturbed (Joley et al., 2003 and Refs. therein).

\subsection{Weed management options}

Although several herbicides are effective (Sheley et al., 1999; DiTomaso, 2005), conventional herbicide control strategies have often been inadequate because of the large areas infested, the economic and environmental costs of herbicides, or the relatively low monetary return from land used for grazing, rights-of-way, conservation or recreation. Other control strategies such as tillage, mowing, burning, and grazing have been evaluated and can sometimes be effective, but are not practical for managing the weed over large areas of rangeland (DiTomaso et al., 2000; DiTomaso, 2005 and Refs. therein). In the Mediterranean region, where it originates, yellow starthistle generally occurs in low densities and appears to be under natural control (Uygur et al., 2004). Research to discover, evaluate, and introduce classical biological control agents began in the 1960s (Maddox, 1981; Rosenthal et al., 1992; Turner et al., 1995; Sheley et al., 1999). Some biological control agents have been previously introduced, with the establishment of six exotic insect species, all of which attack flowerheads and destroy developing seeds (Turner et al., 1995; Balciunas and Villegas, 2001). A few indigenous invertebrates and diseases have been described on yellow starthistle in California (Pitcairn et al., 1999a,b). Of these, only a few attack plants later than the seedling stage, and these have little effect (Klisiewicz, 1986), but some can cause significant mortality among very young seedlings (Woods et al., 2000). The rust pathogen, Puccinia jaceae var. solstitialis, was introduced in California in 2003 (Woods et al., 2004; Fisher et al., 2006), but it does not appear to be causing significant damage to the plant. The combined effect of these natural enemies has not significantly reduced yellow starthistle over most of its range (Balciunas and Villegas, 1999; Pitcairn et al., 2002; Smith, 2002), although there are some local reductions, especially in the presence of competing vegetation (Pitcairn et al., 2005; E.M. Coombs, personal communication). Comparative life history studies of the plant in California (Pitcairn et al., 2002) and Turkey (Uygur et al., 2004) suggest that natural enemies that damage the rosettes may be most effective for controlling it. Additional agents are needed, especially ones that attack the foliage, stem, and roots of rosettes and young bolting plants (Smith, 2004).

\subsection{Life history and behavior of Ceratapion basicorne}

Ceratapion basicorne (Illiger) (Coleoptera: Apionidae) is a weevil native to Europe and the Near East that develops in rosettes of yellow starthistle (Clement et al., 1989; AlonsoZarazaga, 1990a; Wanat, 1994). In the wild this insect has been reared from Ce. solstitialis, Ce. cyanus L., and Cnicus benedictus L., which suggests that it is highly host-specific (Alonso-Zarazaga, 1990a; Wanat, 1994; Campobasso et al., 1999). The insect is common on yellow starthistle in Turkey, Greece, and Georgia (Rosenthal et al., 1994; Balciunas, 1998; Uygur et al., 2005) and is widely distributed in Europe and western Asia (Alonso-Zarazaga, 1990a; Wanat, 1994). Overwintering adults become active in the early spring and feed on rosette leaves (Clement et al., 1989). Eggs are deposited inside leaves, and larvae tunnel down the leaf petiole and develop inside the upper root and basal stem (root crown), where they pupate (Smith and Drew, 2006). Females oviposit about 1.5 eggs per day during an oviposition period of about 20 days. Development time of eggs until eclosion of larvae is 8.5 days at room temperature $\left(19^{\circ} \mathrm{C}\right)$, and development time from oviposition until adult emergence is about 77 days. Adults emerge from the plant in early summer, when it bolts. Adults feed briefly on yellow starthistle foliage then aestivate and hibernate until the following spring. Mating occurs soon after new adults emerge in early summer and after hibernation ends in the following spring (Smith and Drew, 2006). There is one generation per year.

Some data on host specificity were reported by Clement et al. (1989), indicating that Carthamus tinctorius L. (safflower), Galactites tomentosus Moench, and Carduus pycnocephalus L. can support larval development. However, absence of reports of the development of this insect from these hosts in the field (Alonso-Zarazaga, 1990a; Wanat, 1994; Campobasso et al., 1999; Uygur et al., 2005) prompted me to further evaluate its host specificity. The purpose of the present study was to determine what non-target plants are susceptible to damage by $C$. basicorne and to measure the relative amount of damage the insect can cause under no-choice laboratory conditions. Such data provide part of the basis for assessing the risk that the insect would pose to non-target plants if it were to be introduced as a biological control agent (USDA-APHIS, 1998; Withers et al., 1999; Jacob and Briese, 2003; Coombs et al., 2004; Smith, 2006).

\section{Materials and methods}

\subsection{Insect population}

The parental generation and descendents of a colony of C. basicorne held in the USDA-ARS quarantine laboratory in Albany, CA were used for these experiments. The colony was established from adults reared from naturally infested, 
wild yellow starthistle plants that were collected at 15 sites near Kayseri, Sivas, Erzincan, Erzurum, and Malatya, Turkey between 28 May and 2 June 2001 (Smith and Drew, 2006). Emerged adults were identified by the author before using them in experiments. Identification of representative specimens was confirmed by B.A. Korotyaev, and vouchers were deposited at the USDA-ARS Systematic Entomology Laboratory in Beltsville, MD. Reproductive diapause was terminated by holding adults in the dark at $5^{\circ} \mathrm{C}$ for at least three months (Smith and Drew, 2006). Experiments were conducted between March 2002 and April 2005.

\subsection{Test plants}

Test plant species were selected following Technical Advisory Group (TAG) guidelines, which emphasize evaluation of native and economically important species (USDA-APHIS, 1998; see discussion below). We generally used plants grown from seed that were two to four months old and in the rosette stage (except for species that do not form a rosette). However, because of scarcity of seed, many of the Saussurea americana Eaton plants were transplanted from the field. Cuttings of Hemizonia minthornii Jepson were used instead of potted plants. Seeds for test plants were obtained from commercial sources or from the wild with the assistance of cooperators (see Acknowledgements). A representative specimen of each species was grown to maturity to provide herbarium vouchers that are kept at the USDA-ARS Western Regional Research Center, Albany, CA. Identifications were confirmed by G.F. Hrusa (California Department of Food and Agriculture).

\subsection{No-choice tests}

Individual mated females that had completed reproductive diapause were held in a sealed container with a cut leaf of yellow starthistle, inserted in a water vial, until she oviposited (Fig. 1A). Each female was then placed in a clear plastic tube $(3.5 \mathrm{~cm}$ diameter $\times 11 \mathrm{~cm}$ long) mounted on an intact rosette leaf of a nontarget plant species for four to 5 days (Fig. 1B). Afterwards, we put each female back with a cut yellow starthistle leaf for two to three days to determine if she could still oviposit. If the female failed to oviposit on the post-trial yellow starthistle or died during the experiment, then the trial was considered invalid and the experiment was repeated. After removing the insect from the test plant, the exposed leaf was labeled, and we counted the number of adult feeding holes and eggs oviposited. After 10-21 days, which allowed time for eggs to hatch and larvae to tunnel down the petiole and into the root crown, the leaf was removed and examined under a microscope for signs of egg hatch and larval tunneling (see Smith and Drew, 2006). Six weeks after exposure to oviposition, each plant was enclosed in a fine mesh bag and held in a quarantine greenhouse until the insects could complete development (three months), then the plants were dissected to observe signs of insect damage and development. Any plants that deteriorated prematurely were dissected immediately. In general, we tested eight replicates per plant species in the tribe Cardueae and four in the more distantly related taxa. We doubled the number of replicates if there were any signs of larval development.

In general, no statistical tests were conducted on the results, because the purpose was to describe the risk and amount of damage or oviposition rather than to test hypotheses. However, $\chi^{2}$ tests of independence were conducted to compare adult feeding damage and oviposition rates among the varieties of safflower tested to determine if any were more susceptible than the others.

\section{Results and discussion}

\subsection{Test plants}

Test plant species were selected following Technical Advisory Group (TAG) guidelines, which emphasize protection of native and economically important species

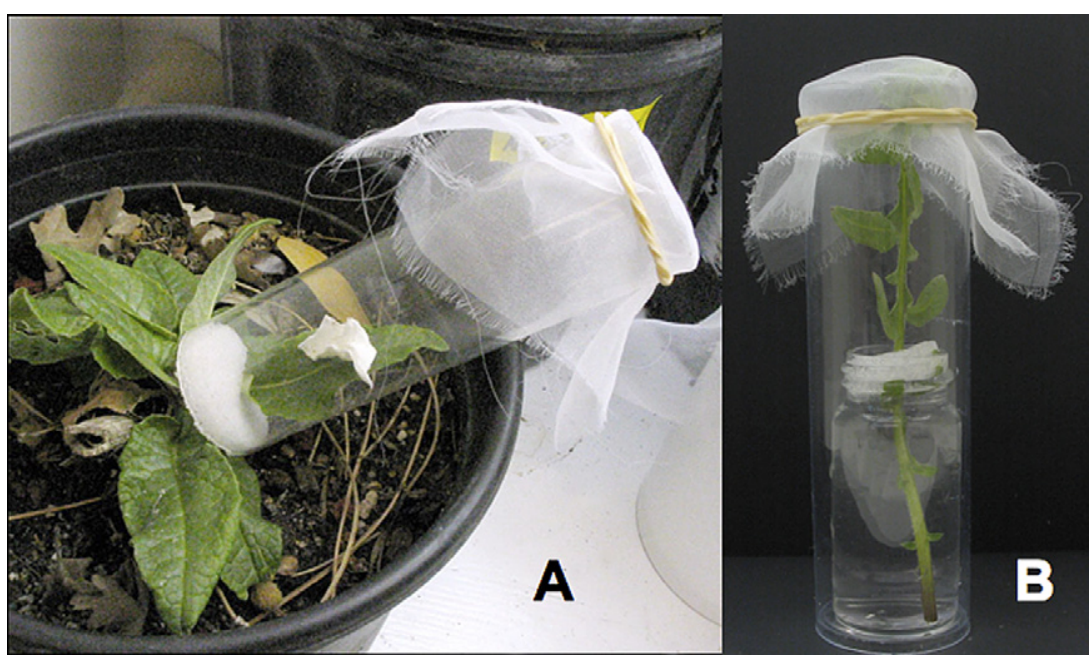

Fig. 1. Individual females were held in a sealed plastic cylinder on an intact leaf of a nontarget test plant for 5 days (A), then placed in a tube with a cut yellow starthistle leaf (B) to feed and oviposit before use in a subsequent test. 
(USDA-APHIS, 1998; TAG, 2006). The guidelines generally follow the "centrifugal phylogenetic" approach outlined by Wapshere (1974), in which more species are tested in taxonomic ranks closely related to the target weed, and the number of test species decreases as relatedness to the target decreases. The validity of this approach is supported by the historical data that indicates that close relatives are most likely to suffer damage (Pemberton, 2000; Sheppard et al., 2005). Other factors that contributed to the choice of test species included: nativity in North America; ornamental or other economic value; whether the species is sympatric with the target's present or potential range in North America; similarity of growth form, life history and secondary chemistry, if known; the presence of rare or protected species in the same genus; and availability of the species for testing. For rare or protected species that were proposed for testing, we often tested a close relative to avoid negatively impacting an already stressed species and/or because of unavailability of specimens. Species names are based on the PLANTS Database (USDA-NRCS, 2006) with the support of other regional flora, primarily Barkley (1986), Keil (1993) and Hitchcock and Cronquist (1998). Test plant species were selected following the higher taxonomy of Bremer (1994). A recent phylogenetic revision (Funk et al., 2005) has changed some taxonomic relationships; however the level of significance of the cladogram branches was not reported, so the relationships should be interpreted as the current, though possibly imperfect, state of knowledge. In particular, the subfamily Cichorioideae was reduced and Carduoideae was erected. The tribe Cardueae was previously placed in the subfamily Cichorioideae s.l.; however, the latter was determined to be a paraphyletic grade (Garcia-Jacas et al., 2002) and has since been redefined as a monophyletic group that does not include Cardueae (Funk et al., 2005). The tribe Mutisieae was removed from Cichorioideae s.s. and is now a basal, probably still paraphyletic, clade of the Asteraceae (Funk et al., 2005).

Yellow starthistle is in the family Asteraceae, subfamily Carduoideae, tribe Cardueae, and subtribe Centaureinae (Bremer, 1994; Funk et al., 2005). Both the subfamily Carduoideae and the tribe Cardueae appear to be monophyletic groups. The exact taxonomic relationships within the tribe Cardueae are not completely understood, but the subtribe Centaureinae segregates as a monophyletic group from the rest of the tribe, whereas the subtribe Carduinae is a paraphyletic grade (Bremer, 1994; Susanna et al., 1995; Garcia-Jacas et al., 2002). However, of the Carduinae genera of interest in this study, Carduus, Cirsium, Cynara, and Silybum appear to be in a monophyletic group, whereas Onopordum is positioned more basally (Funk et al., 2005). So, all these genera are more distantly related to Centaurea than are those in the Centaureinae. The monophyletic Arctium-Cousinia-Saussurea-Jurinea group within the Centaureinae is considered to be the closest related monophyletic group that includes Centaurea, Acroptilon, Carthamus, Cnicus, and probably Crupina (Garcia-Jacas et al., 2002; Funk et al., 2005, J.F. Gaskin, unpublished data).
The two subtribes Centaureinae and Carduinae have distinctly different secondary chemical compounds (Susanna et al., 1995), which are probably important in determining host plant specificity of specialist herbivores. Centaureinae produce acetylene aldehydes, chlorhydrins, and acetates, germacronolide-type sesquiterpenoids, highly methoxylated flavonoids (including flavanones), and fully methoxylated lignans (Wagner, 1997). In contrast, the Carduinae produce distinctive classes of acetylenes, including $\mathrm{C}_{17}$ acetylenes and acetylene glycosides, guainolide-type sesquiterpenoids, monomethoxylated flavonoids, and simple cinnamic acids and their derivatives.

The genus Centaurea is very large, comprising 200-600 species, and its definition and extent is still being resolved (Klokov et al., 1963; Dostál, 1976; Susanna et al., 1995; Garcia-Jacas et al., 2000; Hellwig, 2004). Some groups within the genus Centaurea (e.g., Centaurea sensu stricto, Cyanus, Jacea, and Psephellus groups) appear to be as phylogenetically distinct as other well recognized genera (e.g.., Amberboa, Carduncellus, Carthamus, Cnicus, Crupina, and Seratula) (Garcia-Jacas et al., 2001; J.F. Gaskin, unpublished data). Two North American species, Centaurea americana Nutt. and Centaurea rothrockii Greenm. have been assigned to the genus Plectocephalus, which has distinct pollen morphology and is thought to have diverged from the Centaurea clade during late Oligocene and Miocene (Wagenitz, 1955; Hellwig, 2004). This is much earlier than the divergence of Cyanus and the Carthamus/Carduncellus groups, which probably arose during the Pliocene-Pleistocene transition. The Flora of North America (Keil and Ochsmann, 2006) uses the treatments: Centaurea benedicta $(=C n$. benedictus), Plectocephalus americana and Plectocephalus rothrockii, although the PLANTS website has not adopted these changes (USDA-NRCS, 2006). Although many of the phylogenetic relationships among the remaining species within the genus Centaurea are not precisely known, some groups have clearly emerged. The strongest grouping reflects differences in pollen structure (Wagenitz, 1955) and DNA nucleotide base sequences (Susanna et al., 1995; J.F. Gaskin, unpublished data). Yellow starthistle is in the Jacea group, which is monophyletic and includes many of the other weedy Centaurea species adventive to North America.

Plants of economic interest in the family Asteraceae distributed within the geographic range of yellow starthistle in North America include artichoke (Cynara scolymus L.), safflower ( $\mathrm{Ca}$. tinctorius L.) and sunflower (Helianthus annuus $\mathrm{L}$.). Because a population of $C$. basicorne from Italy has been reported to damage and develop in safflower (Clement et al., 1989), and this is an important crop in California and other western states, we evaluated nine varieties. Bachelor's button (Ce. cyanus) is an introduced ornamental in North America, but is also considered an invasive weed in some areas of the western US (Lorenzi and Jeffery, 1987; Taylor, 1990), and is a common weed in wheat fields in eastern Europe (Voronov, 1977; Kapeluszny and Pawlowski, 1978; Snarska, 2004). The native North American plants 
most closely related to yellow starthistle include: $\mathrm{Ce}$. americana and Ce. rothrockii (discussed above), S. americana, and the many species of Cirsium. Several Cirsium species are becoming rare, and six species or varieties are federally listed as endangered (E) or threatened (T): Cirsium fontinale (Greene) Jepson var. fontinale (E), Ci. fontinale (Greene) Jepson var. obispoense J.T. Howell (E), Ci. hydrophilum (Greene) Jepson var. hydrophilum (E), Cirsium loncholepis Petrak (E), Cirsium pitcheri (Torr. ex Eat.) Torr. and Gray (T), and Cirsium vinaceum Woot. and Standl. (T) (USFWS, 2005). A total of 20 native species, including $C i$. fontinale var. fontinale and Ci. fontinale var. obispoense, occur in California. Eleven California species are considered rare (Tibor, 2001), and Cirsium ciliolatum (Henderson) J.T. Howell and Cirsium rhothophilum Blake are listed by the state of California as endangered and threatened, respectively.

\subsection{No-choice tests}

We tested a total of 51 species of nontarget host plants from the Asteraceae family, including 25 native species and 4 economic species (Table 1). This includes species from all five genera in the subfamily Carduoideae, all three tribes in the subfamily Cichorioideae s.s., and all eight tribes in the subfamily Asteroideae that contain native North American species or economic species. In no-choice oviposition tests, C. basicorne females oviposited at least once on $94 \%$ of the plant species in the subtribe Centaureinae, including $\mathrm{Ca}$. tinctorius (safflower) and the native species Ce. americana and $\mathrm{Ce}$. rothrockii. At least one egg was deposited on $62 \%$ of the plant species in other subtribes of the Cardueae, and most frequently on $\mathrm{S}$. americana and $\mathrm{Ci}$. loncholepis. Eggs were observed on only three plants outside the tribe Cardueae: one egg on one plant of Liatris punctata Hook., two eggs on one plant of Gazania rigens (L.) Gaertn., and six eggs on one plant of Pluchea odorata (L.) Cass. None of the eggs on the first two plants hatched. Two eggs on P. odorata hatched, but larvae died when they reached the end of the petiole. These results indicate no risk of significant larval damage to plants outside the tribe Cardueae.

The highest rates of larval survival and development were observed on Ce. solstitialis (yellow starthistle) and Ce. cyanus (bachelor's button), and there was development on Centaureinae melitensis L. (Napa starthistle, tocalote), Centaureinae montana L., Centaureinae nigrescens Willd. ( = Centaureinae $\mathrm{x}$ pratensis, meadow knapweed), Centaureinae sulphurea Willd., Cn. benedictus L. (blessed thistle), Ca. tinctorius (safflower), and Crupina vulgaris Cass. (common crupina). There was no larval development on any Cirsium species tested, which is consistent with Clement et al.'s (1989) results for Cirsium douglasii DC. and Cirsium campylon $\mathrm{H}$. Sharsm. There was no larval development in any threatened or endangered species, nor their surrogates that we tested. Regarding the two North American native Centaurea species, no development was observed in 18 trials of Ce. rothrockii or 21 trials of Ce. americana. The roots of two $S$. americana plants were damaged, but the damage was not consistent with that usually caused by $C$. basicorne. These plants had been collected from the field shortly before being tested, so it is likely that the damage was caused by other species of insect that had attacked the plant in the field. Other $S$. americana plants that were not infested by $C$. basicorne had similar damage. These results indicate that there is zero to very low risk that $C$. basicorne will damage any North American native plant species.

Our results generally corroborated those of Clement et al. (1989), indicating no larval development on any Cirsium species tested, Cy. scolymus (artichoke) or Ce. calcitrapa L. However, there were some discrepancies. Clement et al. (1989) reported larval development on Car. pycnocephalus L. in $11 \%$ of trials, in which four neonate larvae were transferred to each replicate plant, whereas we observed no development on Car. pycnocephalus, despite oviposition of ten eggs on one out of ten plants tested. The seven eggs oviposited in the leaf blade either did not hatch or the larvae failed to reach the midrib. Of the three eggs oviposited in the midrib, two larvae tunneled down the petiole, but no damage to the stem was observed. Apparently placing neonate larvae in a hole in the central rosette meristem is more conducive to larval development. On the other hand, we observed development of some larvae on Cn. benedictus, whereas Clement et al. (1989) observed no development on the three plants tested. Although we did not test G. tomentosus Moench, absence of development in any Cardueae outside the subtribe Centaureinae, suggests that we would not have observed development in this plant; however, Clement et al. (1989) reported development in $20 \%$ of their larval transfer trials. The differences between our results and those of Clement et al. (1989) indicate that estimates of host plant suitability that are based on transfer of neonate larvae to a potentially susceptible part of the plant (into a hole in the central meristem) can differ from those based on naturally oviposited eggs. The reason is probably because eggs and emerging larvae oviposited in the leaf blade and midrib face different plant defenses than larvae artificially placed in the central meristematic tissue. Thus, when designing larval transfer experiments, it is important to place larvae in as natural a location as possible to improve the validity of extrapolating the results to predict what would occur under natural conditions. Larval transfer is less preferable for insects that oviposit into plant tissue than for those that oviposit externally (Sheppard, 1999).

Development of larvae in safflower and bachelor's button may not be normal for $C$. basicorne because these plants do not form a rosette. Thus, when young larvae tunnel down a leaf on either of these plants, they cannot reach the root crown. The stem of these plants has a pithy center, and larvae only feed in the woody outer portion of the stem. The relatively thin cortex provides a limited space for the insect, and as the plant continues to grow, it sometimes crushes the pupae. Nevertheless, there was high infestation and survivorship to the pupal stage on bachelor's button and safflower in no-choice experiments, so both these 
Table 1

Oviposition and immature development of $C$. basicorne on test plants in no-choice conditions (one female per plant, held in tube on a leaf for 5 days on nontarget species or for $2-3$ days on yellow starthistle)

\begin{tabular}{|c|}
\hline Plant species \\
\hline
\end{tabular}

Subfamily Carduoideae

Tribe Cardueae

Subtribe Centaureinae

Acroptilon repens (L.) DC., Russian knapweed ${ }^{\mathrm{d}}$

Carthamus tinctorius L., safflower

Centaurea americana Nutt., American basketflower ${ }^{\mathrm{b}}$

Centaurea calcitrapa $\mathrm{L} .$, purple starthistle ${ }^{\mathrm{d}}$

Centaurea cineraria $\mathrm{L}$., dusty miller ${ }^{\mathrm{c}}$

Centaurea cyanus L., cornflower, bachelor's button ${ }^{\mathrm{c}, \mathrm{d}}$

Centaurea dealbata Willd., whitewash cornflower ${ }^{\mathrm{d}}$

Centaurea diffusa Lam., diffuse knapweed

Centaurea stoebe L. ( = maculosa), spotted knapweed ${ }^{\mathrm{d}}$

Centaurea melitensis L., Napa starthistle, tocalote ${ }^{\mathrm{d}}$

Centaurea montana L., perennial cornflower ${ }^{\mathrm{c}}$

Centaurea nigrescens Willd. $(=C$. $x$ pratensis $)$, meadow knapweed ${ }^{d}$

Centaurea rothrockii Greenm., Rothrock's basketflower ${ }^{\mathrm{b}}$

Centaurea solstitialis L., yellow starthistle ${ }^{\mathrm{d}}$

Centaurea sulphurea Willd., Sicilian starthistle ${ }^{\mathrm{d}}$

Centaurea virgata Lam. ssp. squarrosa (Willd.) Gugler, squarrose

knapweed $^{\mathrm{d}}$

Cnicus benedictus L., blessed thistle $\mathrm{d}^{\mathrm{d}}$

Crupina vulgaris Cass., common crupina ${ }^{\mathrm{d}}$

Subtribe Carduinae

Carduus pycnocephalus L., Italian thistle

Cirsium brevistylum Cronq. Indian thistle

Cirsium ciliolatum (Henderson) Howell, Ashland thistle ${ }^{\mathrm{b}}$

Cirsium cymosum (Greene) Jepson, peregrine thistle ${ }^{\mathrm{b}}$

Cirsium fontinale Greene var. fontinale, fountain thistle

Cirsium hydrophilum (Greene) Jepson var. vaseyi (Gray) Howell, Mount Tamalpais thistle ${ }^{\mathrm{b}}$

Cirsium loncholepis Petrak, la graciosa thistle ${ }^{\mathrm{b}}$

Cirsium occidentale (Nutt.) Jepson var. venustum (Greene) Jepson. venus thistle ${ }^{\mathrm{b}}$

Cirsium vinaceum Woot and Standl., Sacramento Mountain thistle

Cirsium vulgare (Savi) Ten., bull thistle ${ }^{\mathrm{d}}$

Cynara scolymus L., artichoke

Onopordum acanthium L., Scotch thistle

Saussurea americana Eaton, American sawwort

Silybum marianum (L.) Gaertn., milk thistle ${ }^{\mathrm{d}}$

Subtribe Carlininae

Xeranthemum cylindraceum Sibth. and Sm., lilac stars ${ }^{\mathrm{c}}$

Subtribe Echinopsidinae

Echinops exaltatus Schrad., tall globethistle

\begin{tabular}{|c|c|c|c|c|c|c|c|}
\hline 10 & $4.09 \pm 0.82$ & $0.16 \pm 0.06$ & 9 & 90 & 40 & 0 & 0 \\
\hline 100 & $10.66 \pm 0.82$ & $0.47 \pm 0.05$ & 76 & 57 & 61 & 42 & 38 \\
\hline 23 & $6.04 \pm 1.42$ & $0.22 \pm 0.08$ & 21 & 91 & 39 & 0 & 0 \\
\hline 8 & $9.59 \pm 2.20$ & $0.25 \pm 0.08$ & 8 & 100 & 75 & 0 & 0 \\
\hline 10 & $0.51 \pm 0.13$ & $0.00 \pm 0.00$ & 10 & 80 & 0 & 0 & 0 \\
\hline 8 & $22.66 \pm 3.30$ & $1.73 \pm 0.29$ & 8 & 100 & 100 & 100 & 100 \\
\hline 11 & $10.71 \pm 2.54$ & $0.85 \pm 0.30$ & 13 & 100 & 82 & 9 & 0 \\
\hline 8 & $24.28 \pm 5.22$ & $1.50 \pm 0.43$ & 7 & 100 & 88 & 0 & 0 \\
\hline 8 & $8.84 \pm 1.78$ & $0.56 \pm 0.13$ & 6 & 100 & 75 & 0 & 0 \\
\hline 20 & $11.25 \pm 2.01$ & $0.60 \pm 0.12$ & 17 & 95 & 75 & 44 & 44 \\
\hline 17 & $4.31 \pm 2.04$ & $0.25 \pm 0.15$ & 15 & 53 & 35 & 13 & 7 \\
\hline 14 & $10.24 \pm 2.25$ & $0.74 \pm 0.21$ & 15 & 93 & 64 & 42 & 10 \\
\hline 18 & $12.83 \pm 1.91$ & $0.30 \pm 0.09$ & 15 & 100 & 56 & 0 & 0 \\
\hline 349 & $16.58 \pm 0.46$ & $1.54 \pm 0.05$ & 32 & 100 & 99 & 89 & 88 \\
\hline 13 & $5.18 \pm 1.13$ & $0.34 \pm 0.13$ & 12 & 77 & 54 & 10 & 10 \\
\hline 16 & $7.91 \pm 1.11$ & $0.51 \pm 0.12$ & 10 & 100 & 81 & 0 & 0 \\
\hline 8 & $5.58 \pm 1.14$ & $0.50 \pm 0.17$ & 9 & 100 & 88 & 50 & 38 \\
\hline 9 & $3.51 \pm 1.12$ & $0.24 \pm 0.13$ & 11 & 89 & 44 & 22 & 22 \\
\hline 10 & $1.74 \pm 1.63$ & $0.20 \pm 0.20$ & 9 & 40 & 10 & 0 & 0 \\
\hline 7 & $0.00 \pm 0.00$ & $0.11 \pm 0.07$ & 7 & 0 & 29 & 0 & 0 \\
\hline 9 & $0.13 \pm 0.09$ & $0.00 \pm 0.00$ & 9 & 22 & 0 & 0 & 0 \\
\hline 11 & $0.10 \pm 0.06$ & $0.00 \pm 0.00$ & 8 & 18 & 0 & 0 & 0 \\
\hline 15 & $0.06 \pm 0.03$ & $0.00 \pm 0.00$ & 15 & 27 & 0 & 0 & 0 \\
\hline 16 & $0.70 \pm 0.39$ & $0.07 \pm 0.05$ & 16 & 56 & 13 & 0 & 0 \\
\hline 9 & $4.04 \pm 1.92$ & $0.36 \pm 0.24$ & 9 & 78 & 56 & 0 & 0 \\
\hline 16 & $1.40 \pm 1.09$ & $0.03 \pm 0.03$ & 15 & 44 & 6 & 0 & 0 \\
\hline 7 & $0.00 \pm 0.00$ & $0.00 \pm 0.00$ & 7 & 0 & 0 & 0 & 0 \\
\hline 8 & $0.44 \pm 0.44$ & $0.06 \pm 0.06$ & 8 & 13 & 13 & 0 & 0 \\
\hline 11 & $1.18 \pm 0.64$ & $0.00 \pm 0.00$ & 11 & 55 & 0 & 0 & 0 \\
\hline 8 & $0.75 \pm 0.30$ & $0.06 \pm 0.04$ & 8 & 88 & 25 & 0 & 0 \\
\hline 41 & $4.04 \pm 0.91$ & $0.35 \pm 0.07$ & 23 & 73 & 51 & $0^{\mathrm{e}}$ & $0^{\mathrm{e}}$ \\
\hline 8 & $0.19 \pm 0.10$ & $0.00 \pm 0.00$ & 8 & 38 & 0 & 0 & 0 \\
\hline 4 & $3.35 \pm 2.89$ & $0.25 \pm 0.25$ & 4 & 75 & 25 & 0 & 0 \\
\hline 4 & $1.85 \pm 0.88$ & $0.05 \pm 0.05$ & 4 & 100 & 25 & 0 & 0 \\
\hline
\end{tabular}


No. of trials Adult feeding Eggs/day

oviposition holes/day $( \pm \mathrm{SE})( \pm \mathrm{SE})$
No. of trials

development ${ }^{\mathrm{a}}$
Percentage of trials

Adult feeding Eggs Internal plant Adults or holes present present damage present pupae present

Subfamily Cichorioideae s.s.

Tribe Arctoteae

Gazania rigens (L.) Gaertn., treasure-flower ${ }^{\mathrm{c}}$
10

Tribe Lactuceae

Agoseris grandiflora (Nutt.) Greene, bigflower agoseris

Stephanomeria cichoriacea Gray, chicoryleaf wirelettuce ${ }^{\mathrm{b}}$

Lactuca sativa L., garden lettuce

Tribe Vernonieae

Stokesia laevis (Hill) Greene, Stokes' aster ${ }^{\mathrm{b}}$

Subfamily Asteroideae

Tribe Anthemideae

Artemisia californica Less., coastal sagebrush ${ }^{\mathrm{b}}$

Tribe Astereae

Symphyotrichum ( = Aster) chilense (Nees) Nesom var. chilense, Pacific aster ${ }^{\mathrm{b}}$

Tribe Eupatorieae

Brickellia californica (Torr. and Gray) Gray, California brickellbush ${ }^{\mathrm{b}}$

Liatris punctata Hook., dotted blazing star ${ }^{\mathrm{b}}$

Tribe Gnaphalieae

Pseudognaphalium (= Gnaphalium) californicum (DC.) A. Anderb., ladies' tobacco ${ }^{\mathrm{b}}$

Tribe Helenieae

Eriophyllum staechadifolium Lag., seaside woolly sunflower ${ }^{\mathrm{b}}$

Hemizonia minthornii Jepson, Santa Susana tarweed ${ }^{\mathrm{b}}$

Tribe Heliantheae

Echinacea purpurea (L.) Moench, eastern purple coneflower ${ }^{\mathrm{b}}$

Helianthus annuus $\mathrm{L}$., common sunflower ${ }^{\mathrm{b}}$

Tribe Inuleae (formerly in Plucheeae)

Pluchea odorata (L.) Cass., salt marsh fleabane ${ }^{\mathrm{b}}$

Tribe Senecioneae

Senecio cineraria DC., silver ragwort ${ }^{\mathrm{c}}$

Senecio vulgaris L., old-man-in-the-Spring ${ }^{\mathrm{d}}$

Grade 1 (formerly in Cichorioideae)

Tribe Mutisieae s.s.

Trixis californica Kellogg, American threefold ${ }^{\mathrm{b}}$

5
$0.00 \pm 0.00$

$0.00 \pm 0.00$

$0.00 \pm 0.00$

$0.00 \pm 0.00$

$0.04 \pm 0.04 \quad 10$

$0.00 \pm 0.00 \quad 8$

$0.00 \pm 0.00 \quad 2$

$0.00 \pm 0.00 \quad 8$

$0.00 \pm 0.00 \quad 4$

$0.33 \pm 0.33$

$0.00 \pm 0.00 \quad 6$

$0.00 \pm 0.00$

$0.00 \pm 0.00 \quad 5$

$0.35 \pm 0.17$

$0.72 \pm 0.40$

$0.00 \pm 0.00 \quad 4$

$0.04 \pm 0.04 \quad 4$

$0.00 \pm 0.00$

$0.00 \pm 0.00 \quad 5$

$0.37 \pm 0.20$

$0.00 \pm 0.00$

$0.00 \pm 0.00 \quad 7$

$0.00 \pm 0.00 \quad 4$

$0.17 \pm 0.17$

$0.00 \pm 0.00 \quad 6$

$0.00 \pm 0.00 \quad 4$

$0.13 \pm 0.10$

$0.20 \pm 0.20 \quad 6$

$0.00 \pm 0.00$

$0.35 \pm 0.35$

$0.00 \pm 0.00 \quad 6$

$0.00 \pm 0.00 \quad 4$

$0.00 \pm 0.00 \quad 5$

40

$0.12 \pm 0.08$

40

0

0

17

0

75

60

0

43

0

17

0

33

0

25

al. (2005).

a Number of trials for insect development was less than the number of oviposition trials when plants were discarded because of deterioration caused by other factors.

b Native to North America.

c Alien ornamental.

${ }^{d}$ Alien weed.

e Two S. americana plants were damaged, but the damage was not consistent with $C$. basicorne. Other plants not infested by $C$. basicorne had similar damage, which was presumably caused by infestation by other insects in the field before entry to quarantine laboratory. 
plants require additional choice testing in the laboratory and field to determine risk of infestation under more natural conditions (Smith et al., 2006).

The host plants suitable for $C$. basicorne development correspond to a clearly defined phylogenetic group. Our results indicate that $C$. basicorne is able to develop on a small number of plants within a monophyletic "derived clade" within the subtribe Centaureinae that includes the Jacea, Cyanus and Carthamus groups (Fig. 2). Delineation of this clade is based on nucleotide sequences of ITS nuclear ribosomal DNA and agrees with other morphological characters (Garcia-Jacas et al., 2001); however, the relationships within it are not fully certain because of low bootstrap values (J.F. Gaskin, unpublished data). The clade includes the suitable species: Ce. solstitialis, Ce. melitensis, $\mathrm{Ce}$. nigrescens, Ce. sulphurea and Cn. benedictus in the Jacea group, Ce. cyanus and Ce. montana in the Cyanus group, and $\mathrm{Ca}$. tinctorius in the Carthamus group (GarciaJacas et al., 2001; J.F. Gaskin, unpublished data). Within this clade, there are no native North American plants, and the only plants of economic interest are $\mathrm{Ca}$. tinctorius, a significant crop, and Ce. cyanus, an ornamental. The two native North American species, Ce. americana and $\mathrm{Ce}$. rothrockii, which were not suitable hosts, are in a different clade and have recently been assigned to the genus Plectocephalus (Susanna et al., 1995; Hellwig, 2004). Cr. vulgaris may be an outlier because it appears to be more distantly related to $\mathrm{Ce}$. solstitialis than other groups containing unsuitable plants: Acroptilon, Plectocephalus and Psephellus. Some species within the "derived clade" were not suitable for C. basicorne development: Ce. calcitrapa, Ce. cineraria, Centaurea diffusa, and Centaurea stoebe (often called Centaurea maculosa in North America (Ochsmann, 2001)). So, although the "derived clade" includes almost all

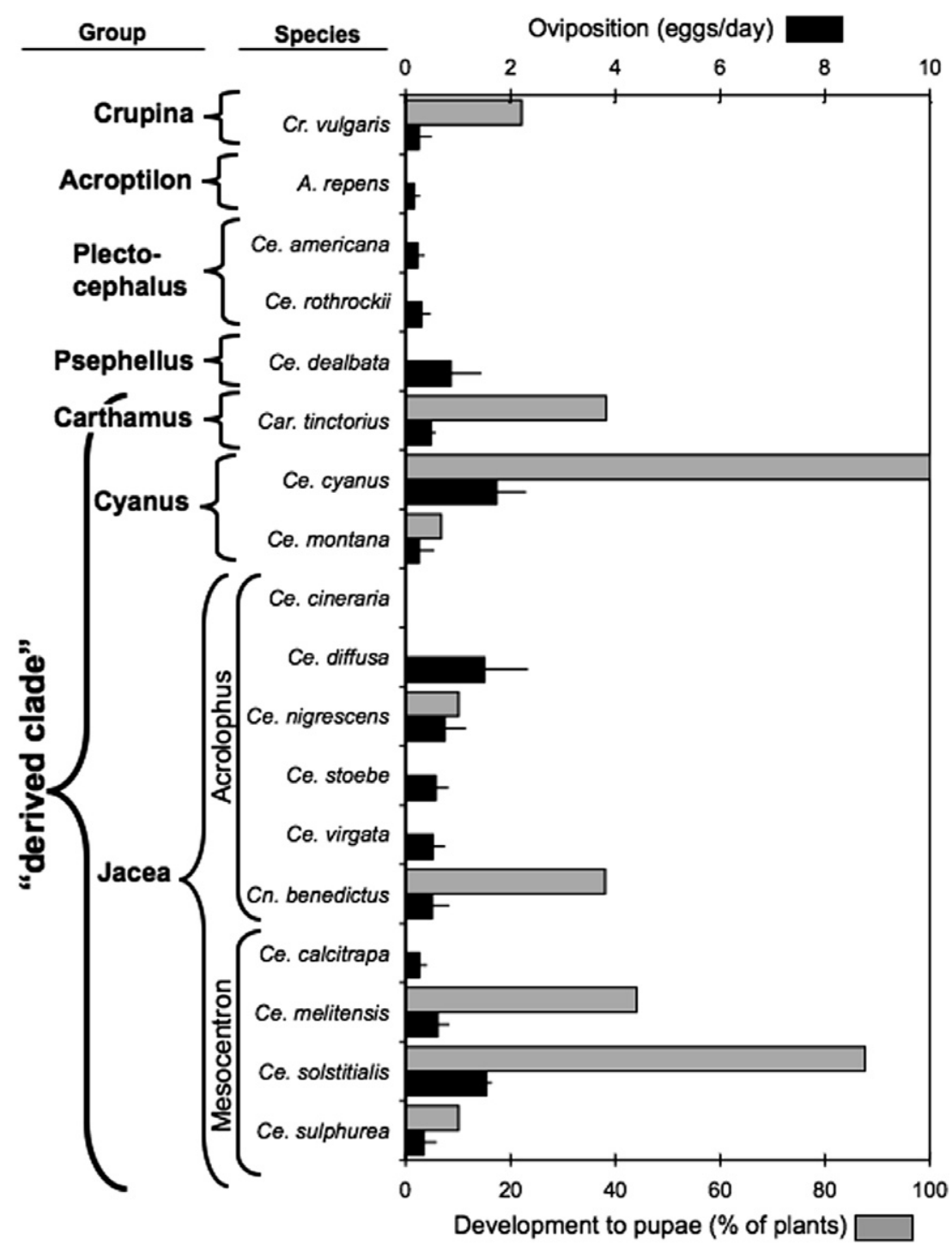

Fig. 2. Suitability of plants within the subtribe Centaureinae to oviposition and larval development by C. basicorne. Classification of the species into "groups" is based on plant morphology, pollen type and DNA sequences of introns (Garcia-Jacas et al., 2001; J.F. Gaskin, unpublished data). Oviposition is mean eggs per female per day of exposure to the plant $( \pm 95 \% \mathrm{CI})$, and development is percentage of oviposition trials in which at least one insect developed to at least the pupal stage. 
species that are suitable, not all species within the clade are suitable. These results confirm that although phylogenetic relationships explain a high degree of host plant specificity, they do not explain all of it. The exceptions presumably are caused by evolutionary divergence of critical characters (e.g., allelochemics and plant morphology) in close relatives that cause them to be less suitable, and evolutionary convergence in more distant relatives that make them more suitable. Thus, selection of plant species to test should not rely only on phylogeny, as some have proposed (Briese, 2005,2006 ), lest we overlook a more distant relative that may be suitable because of similarity of critical characters (e.g., Wheeler, 2005; Haines et al., 2004).

All the reported larval host plants from field collections: $\mathrm{Ce}$. solstitialis, Ce. cyanus, and Cn. benedictus (AlonsoZarazaga, 1990a; Wanat, 1994; Campobasso et al., 1999; J. Balciunas, unpublished data) were suitable in the laboratory experiments. However, other species that were suitable in the laboratory, such as $\mathrm{Ca}$. tinctorius, $\mathrm{Ce}$. melitensis, $\mathrm{Ce}$. sulphurea, Ce. nigrescens and Ce. montana, have not been reported as a host in the field. This agrees with current theory that the physiological range, delineated in no-choice laboratory experiments, is broader than the ecological range realized in the field (Briese, 2005; Sheppard et al., 2005). Field experiments conducted in Turkey indicated that $C a$. tinctorius was not attacked by $C$. basicorne, despite natural infestation of $48-98 \%$ of adjacent Ce. solstitialis plants (Smith et al., 2006). Thus, Ca. tinctorius is not likely to be attacked in the field. Similar experiments have not been done for Ce. cyanus, so risk to this species in the field is not well known.

Intensity of adult feeding on leaves was highly correlated to the number of eggs oviposited in test plants $\left(R^{2}=0.88\right.$, $P<0.0001$; Fig. 3), probably because adult feeding is necessary for egg development. Adult feeding damage was highest on Ce. solstitialis (yellow starthistle), Ce. cyanus (bachelor's button) and Ce. diffusa Lam. (diffuse knapweed) (Fig. 3 and Table 1). Feeding rate on Ce. solstitialis may have been underestimated because (1) exposure was usually for 3 days on cut leaves versus for 5 days on intact plants

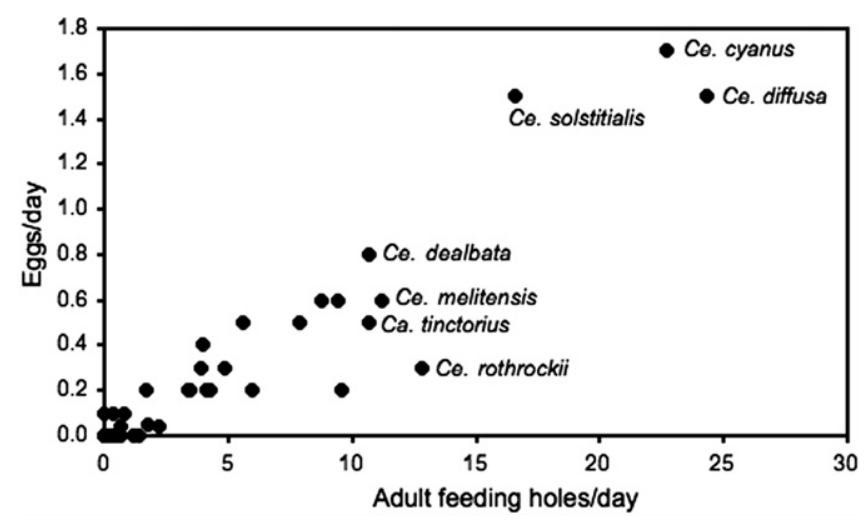

Fig. 3. Relationship of mean number of adult feeding holes (ca. 1- $\mathrm{mm}^{2}$ ) to mean number of eggs on the different test plant species under no-choice conditions. Each point represents a different test plant species $(\mathrm{YST}=$ Centaurea solstitialis, safflower $=$ Ca. tinctorius $)$. for nontarget species, and (2) it included the "positive control" trials that followed exposure to nontarget plants, many of which may have negatively affected the insects. There was moderate acceptance of nine other species of Centaurea, Ca. tinctorius (safflower) and Cn. benedictus. Low adult feeding occurred on the other Centaureinae, about half the other Cardueae, and one other species of Cichorioideae ( $G$. rigens). There was, at most, only trace feeding on test plants in the subfamily Asteroideae. These results suggest that under extreme conditions $C$. basicorne adults may feed on other species of plants, particularly in the subtribe Centaureinae. Risk of adult feeding damage is generally limited to plants within the tribe Cardueae. Each adult feeding hole is about $1-\mathrm{mm}^{2}$, and they were smaller on most nontarget species. Therefore, adult feeding is not expected to cause any noticeable damage to nontarget species except possibly to Ce. cyanus and Ce. diffusa.

\subsection{Safflower varieties}

All nine safflower varieties were susceptible to adult feeding and oviposition under no-choice conditions (Table 2). Adult feeding (7.4-16.2 holes/days) and oviposition (0.30.8 eggs/days) rates tended to be lower than on yellow starthistle (16.6 and 1.5 , respectively) but are clearly a concern regarding susceptibility of this plant. Larval damage and development to at least the pupal stage occurred in 30-50\% of plants tested, depending on variety. There were no significant differences among varieties $\left(\chi^{2}, d f=9, P>0.5\right)$, even when varieties with less than ten replicates were excluded from analysis. These results confirm those of Clement et al. (1989) indicating that C. basicorne is physiologically able to feed, oviposit and develop on safflower under no-choice laboratory conditions.

\subsection{Relationship of host range to Ceratapion phylogeny}

The genus Ceratapion contains 55 species and subspecies, divided among five subgenera: Acanephodous, Ceratapion, Clementiellus, Echinostroma, and Angustapion (Wanat, 1994). Most speciation occurred in Pliocene-Miocene, with the last events in the Pleistocene Glacial Period (including vicariance of sibling species). Species are distributed almost throughout the entire Palearctic. In general, larvae and adults of species in the genus Ceratapion feed only on Asteraceae in the tribe Cardueae (= "Cynareae") (Alonso-Zarazaga, 1990b). Genera recorded as food plants are: Arctium, Carduus, Centaurea, Cirsium, Cynara, Echinops, Galactites, Onopordum, Silybum, and Xeranthemum. Hypotheses of the phylogenetic relationships among species of Ceratapion have been proposed by Alonso-Zarazaga (1990a) and Wanat (1994), based on morphological characters (Fig. 4). Species in the subgenus Echinostroma, which includes C. basicorne, are associated with plants in the genera Arctium, Carlina, Carthamus, Centaurea and Silybum (Alonso-Zarazaga, 1990a; Wanat, 1994). Larval host plants of Ceratapion curtii (Wagner), the closest relative of 
Table 2

Physiological suitability of different varieties of safflower to oviposition and development of Ceratapion basicorne in a no-choice oviposition experiment

\begin{tabular}{|c|c|c|c|c|c|c|c|c|}
\hline \multirow{2}{*}{$\begin{array}{l}\text { Safflower } \\
\text { variety }^{\mathrm{a}}\end{array}$} & \multirow{2}{*}{$\begin{array}{l}\text { No. of trials } \\
\text { oviposition }\end{array}$} & \multirow{2}{*}{$\begin{array}{l}\text { Adult feeding } \\
\text { holes/day }\end{array}$} & \multirow[t]{2}{*}{ Eggs/day } & \multirow{2}{*}{$\begin{array}{l}\text { No. of trials } \\
\text { development }\end{array}$} & \multicolumn{4}{|c|}{ Percentage of trials } \\
\hline & & & & & $\begin{array}{l}\text { Adult feeding } \\
\text { holes present }\end{array}$ & $\begin{array}{l}\text { Eggs } \\
\text { present }\end{array}$ & $\begin{array}{l}\text { Internal plant } \\
\text { damage present }\end{array}$ & $\begin{array}{l}\text { Adults or } \\
\text { pupae present }\end{array}$ \\
\hline$\overline{\mathrm{CW}}-88-\mathrm{OL}^{\mathrm{b}}$ & 23 & 10.7 & 0.6 & 10 & 91 & 61 & 50 & 50 \\
\hline CW-1221 & 16 & 16.2 & 0.4 & 16 & 44 & 63 & 31 & 31 \\
\hline CW-4440 & 16 & 9.1 & 0.5 & 15 & 38 & 63 & 40 & 40 \\
\hline Gila $^{\mathrm{c}}$ & 10 & 7.4 & 0.4 & - & 80 & 80 & - & - \\
\hline Hartman $^{\mathrm{d}}$ & 7 & - & 0.3 & 7 & - & 43 & 43 & 43 \\
\hline S-345-OL & 6 & 14.8 & 0.8 & 6 & 100 & 67 & 50 & 33 \\
\hline $\mathrm{S}-400^{\mathrm{d}}$ & 2 & - & 0.3 & 2 & - & 100 & 50 & 0 \\
\hline S-518-OL & 10 & 8.4 & 0.4 & 10 & 90 & 50 & 40 & 30 \\
\hline $\mathrm{S}-541^{\mathrm{d}}$ & 10 & - & 0.4 & 10 & - & 50 & 50 & 50 \\
\hline
\end{tabular}

a Seed producers: CW, CalWest; S, SeedTec; OL, high oleic oil content.

b Cut leaves in vials were used in 12 trials of CW-88, for which no development data are available.

${ }^{c}$ No development data are available because plants died during malfunction of cooling system.

d Adult feeding holes were not counted.

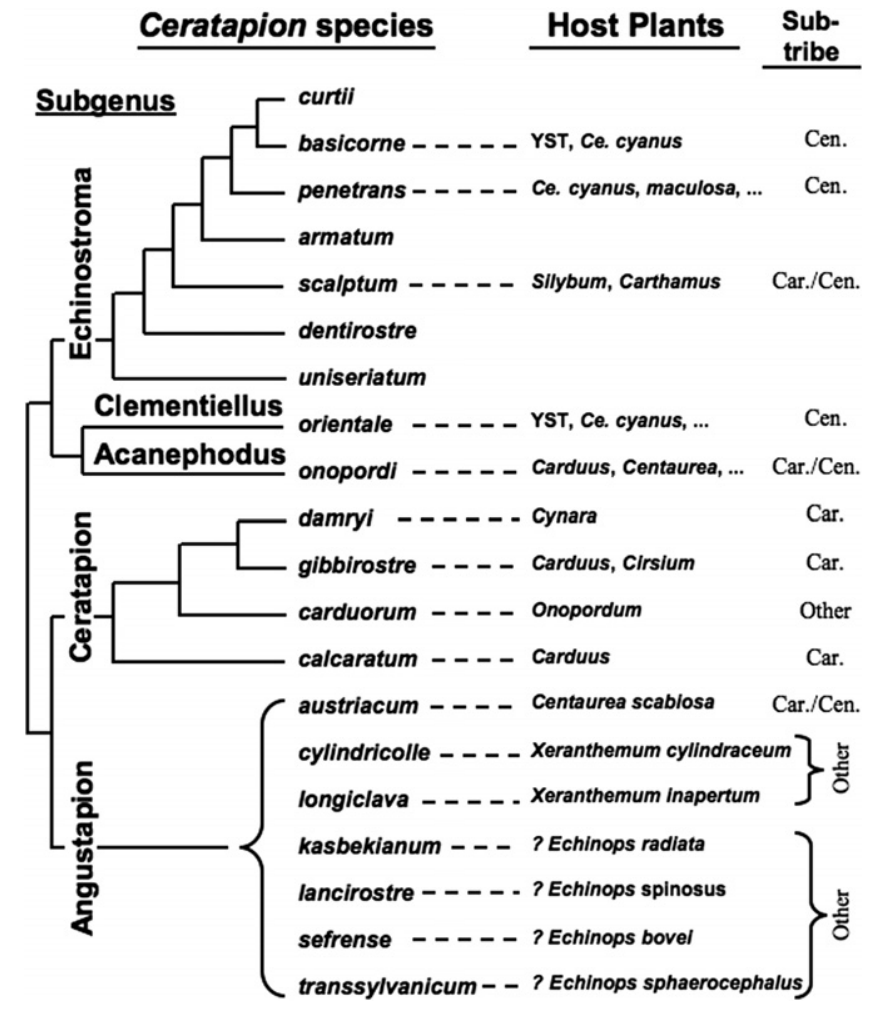

Fig. 4. Phylogenetic relationships among species and subgenera in the genus Ceratapion are after Alonso-Zarazaga (1990a) and Wanat (1994). Larval host records are from both authors and Balciunas (unpublished data). Hosts of C. curtii, C. armatum, C. dentirostre and C. uniseriatum are unknown. All host plants are in the tribe Cardueae, and subtribe assignments are from Funk et al. (2005). (YST, Ce. solstitialis; “...”, other Cardueae species; "?", uncertain host plant).

C. basicorne, are unknown. Reported hosts of the next closest relative, Ceratapion penetrans (Germar), which has three subspecies, are: Centaurea rhenana $[=$ stoebe, $=$ maculosa, = paniculata $]$, Centaurea jacea, Ce. cyanus, Ce. diffusa, Centaurea nigra, Centaurea scabiosa, and Ce. solstitialis (Alonso-Zarazaga, 1990a; Wanat, 1994; Balciunas unpublished data). Older reports of Arctium lappa and Carlina vulgaris (Ehret, 1983) as hosts for this species may be mistaken. Ceratapion scalptum (Mulsant and Rey), which is also in the same subgenus, has one subspecies that develops on Carthamus and another on Silybum. Thus, each of the species or subspecies in the subgenus Echinostroma appear to develop only on plants within a genus. The historical restriction of evolutionary radiation of species within the genus Ceratapion to host plants within the Cardueae, and of species within the subgenus Echinostroma to a few genera within the Cardueae, suggests that $C$. basicorne is not likely to ever adapt to host plants outside this tribe. Interestingly, the two species that attack crops, Cer. scalptum (Mulsant and Rey) on safflower and Ceratapion damryi (Desbrochers) on artichoke (Cy. scolymus), are very specific and have never been reported to develop on Ce. solstitialis or Ce. cyanus. So, conversely, it is not surprising that C. basicorne, which is specific to the latter species, does not develop on either of the former species, at least under field conditions (Smith et al., 2006).

The current theories on the phylogeny of species within the tribe Cardueae (Bremer, 1994; Susanna et al., 1995; Garcia-Jacas et al., 2002; Funk et al., 2005) and the genus Ceratapion (Alonso-Zarazaga, 1990a; Wanat, 1994) suggest that there is not an overall one-to-one pattern of Ceratapion species coevolving with Cardueae species (Fig. 4). For example, Ceratapion onopordi appears to be relatively polyphagous, being reported from hosts in six genera from both the Centaureinae and Carduinae (Alonso-Zarazaga, 1990a; Wanat, 1994). The two Cer. scalptum subspecies attack different genera in different subtribes (Carthamus spp. [Centaureinae] and Silybum marianum [Carduinae]), suggesting taxonomically how far a species in this group can jump when adopting a new host. However, most of the species in the subgenera Echinostroma, Clementiellus and Acanephodus, for which host plants are known, use hosts in the Centaureinae (especially Centaurea and Carthamus species); however, Silybum is in the Carduinae. Species in the subgenus Ceratapion are associated with Carduinae (Carduus, Cirsium, Cynara, and Onopordum), and those in 
the subgenus Angustapion are generally associated with more basal taxa of the Cardueae (Echinops, Xeranthemum), but one species is associated with Ce. scabiosa.

Although all Ceratapion species are restricted to plants in the tribe Cardueae, they vary in their degree of host plant specificity. Because all species within the subgenus Echinostroma are only known to develop on plants in the Centaureinae and Carduinae, it appears that $C$. basicorne and its recent ancestors have been specializing on these host plants for a long time. This suggests that host plant specificity is deeply ingrained and that the insect is not likely to drastically change its host range. Thus, it appears that if $C$. basicorne were to adopt a new host after being released in North America, it would most likely be a close relative of $C e$. solstitialis and Ce. cyanus. The closest native species are Ce. americana and Ce. rothrockii, but they are so distantly related as to be considered in a different genus (Plectocephalus), and they were not able to sustain larval development in our no-choice experiments. Therefore, it seems improbable that the insect could adapt to developing on any native North American species in the foreseeable future.

\section{Conclusions}

The no-choice results indicate that no plant species outside the subtribe Centaureinae are at risk of significant larval damage. Although adult feeding on foliage and oviposition occurred on many nontarget plants under nochoice conditions, they were at much lower rates than on Ce. solstitialis, Ce. cyanus and Ce. diffusa. Under choice conditions, the nontarget attack rates would be expected to be lower. Because $C$. basicorne is synovigenic, and must feed to continue producing eggs, absence of its preferred host plant would probably reduce egg production and consequently the risk of oviposition on nontarget plants. The oviposition rates that we observed on nontarget plants are probably elevated because of feeding on Ce. solstitialis prior to exposure to each nontarget test plant. Nontarget plants that supported oviposition and larval development warrant further evaluation under choice conditions to further assess the degree to which they are at risk. These include the two cultivated species: $\mathrm{Ca}$. tinctorius (safflower) and Ce. cyanus (bachelor's button), and the native North American species: Ce. americana, Ce. rothrockii, Ci. loncholepis and S. americana. Larval damage to Acroptilon repens, Cn. benedictus, Cr. vulgaris and the other Centaurea species is acceptable because are all alien noxious weeds in North America.

Successful development of an insect on a crop in laboratory experiments is usually sufficient to discourage further evaluation of it as a biological control agent. However, the absence of field records of $C$. basicorne developing on safflower, despite records of its close relative, Cer. scalptum, on this plant, suggest that risk to safflower under field conditions may be insignificant. Only by conducting further choice experiments under laboratory or field conditions can we improve our estimation of this risk. Field trials that were conducted at sites with natural populations of $C$. basicorne in Turkey showed no larval development on safflower by C. basicorne (Smith et al., 2006). However, three other insects did develop on safflower: Cer. scalptum, Ceratapion orientale, and Ceratapion onopordi. Therefore, if C. basicorne is approved for release, it will be important to correctly identify all specimens to prevent accidental introduction of any of these species. Taxonomic keys with detailed illustrations have been developed to assist proper identification of C. basicorne (J.K. Balciunas and B.A. Korotyaev, unpublished manuscript).

Centaurea cyanus (bachelor's button) is at risk of adult feeding, oviposition and larval damage. This plant has previously been reported as a host of $C$. basicorne in its native range in Eurasia, but the frequency of such attack has not been studied. The plant is both an ornamental and an invasive weed in parts of North America. The developing larva causes a small swelling of the stem at the base of the petiole down which it tunneled. Although this may cause cosmetic damage to the ornamental, it is not known how frequently this may occur, especially when the plant is grown as an intensively managed monoculture. Because this plant is an invasive weed in some regions of the western US, damage to it in rangeland habitats would be beneficial.

\section{Acknowledgments}

I thank M. Pitcairn, P. Akers and B. Villegas (CDFA); J. Sigg and D. Dibor (California Native Plant Soc.); Bruce Baldwin (U.C. Berkeley); J. Littlefield (Montana St. U.) and W.L. Bruckart (USDA-ARS) for assistance preparing the host plant test list. Test plant seeds were obtained with the assistance of M. Pitcairn, D. Woods, P. Akers, B. Villegas, and C. Pirosko (CDFA), R. Deering (U.C. Davis), P.J. Griffin (Siskiyou County), A. Yost (US Forest Service), H. Forbes (U.C. Berkeley), J. Herr (USDA-ARS), and S. Edwards (East Bay Regional Park District). M. Cristofaro and C. Tronci (ENEA C.R. Casaccia, Italy) discovered sites in Turkey and helped me collect C. basicorne for these studies. Drs. J. Balciunas and S.L. Clement (USDA-ARS) provided useful advice for conducting this research and comments on the manuscript. California Department of Transportation provided partial funding for this research. My assistants D. Boughter, K.J. Baxter, A.E. Drew, M.J. Kabler, R. Chang and M.I. Wibawa helped obtain and grow test plants, maintain the insect colony and conduct laboratory experiments. Insects were identified by B.A. Korotyaev (Russian Acad. Sci.), and E. Colonnelli (U. of Rome), and plants by G.F. Hrusa (CDFA).

\section{References}

Alonso-Zarazaga, M.A., 1990a. Revision of the sub-genera Ceratapion S. Str. and Echinostroma Nov. of the genus Ceratapion Schilsky, 1901. Fragmenta Entomologica, Roma 22, 399-528.

Alonso-Zarazaga, M.A., 1990b. Revision of the supraspecific taxa in the Palaearctic Apionidae Schoenherr, 1823 (Colepotera, Curculionoidea). 
2. Subfamily Apioninae Schoenherr, 1823: Introduction, keys and descriptions. Graellsia 46, 19-156.

Balciunas, J., 1998. The future of biological control for yellow starthistle In: Hoddle, M.S. (Ed.), Proceedings, California Conference on Biological Control: innovations in Biological Control Research, 10-11 June 1998. University of California, Berkeley, CA, pp. 93-95.

Balciunas, J., Villegas, B., 1999. Two new seed head flies attack yellow starthistle. California Agriculture 531, 8-11.

Balciunas, J.K., Villegas, B., 2001. Unintentionally released Chaetorellia succinea (Diptera: Tephritidae): Is this natural enemy of yellow starthistle a threat to safflower growers? Environmental Entomology 30, 953-963.

Barkley, T.M., 1986. Asteraceae Dum., the sunflower family. In: McGregor, R.L., Barkley, T.M., Brooks, R.E., Schofield, E.K. (Eds.), Flora of the Great Plains. Great Plains Flora Association. University Press of Kansas, Lawrence, Kansas, pp. 838-1021.

Bremer, K., 1994. Asteraceae: Cladistics and Classification. Timber Press, Portland, Oregon.

Briese, D.T., 2005. Translating host-specificity test results into the real world: the need to harmonize the yin and yang of current testing procedures. Biological Control 35, 208-214.

Briese, D.T., 2006. Host specificity testing of weed biological control agents: initial attempts to modernize the centrifugal phylogenetic method. In: Hoddle, M.S., Johnson, M.W. (Eds.), Proceedings of the Fifth California Conference on Biological Control, 25-27 July 2006, The Historic Mission Inn, Riverside, CA. CCBC V, CCBC-V, pp. $32-39$.

Campobasso, G., Colonnelli, E., Knutson, L., Terragitti, G., Cristofaro, M. (Eds.), 1999. Wild plants and their associated insects in the Palearctic region, primarily Europe and the Middle East. United States Department of Agriculture, Agricultural Research Service, ARS-147.

Clement, S.L., Alonso-Zarazaga, M.A., Mimmocchi, T., Cristofaro, M., 1989. Life history and host range of Ceratapion basicorne (Coleoptera: Apionidae) with notes on other weevil associates (Apioninae) of yellow starthistle in Italy and Greece. Annals of the Entomological Society of America 82, 741-747.

Coombs, E.M., Schooler, S.S., McEvoy, P.B., 2004. Nontarget impacts of biological control agents. In: Coombs, E.M., Clark, J.K., Piper, G.L., Cofrancesco, Jr., A.F. (Eds.), Biological Control of Invasive Plants in the United States. Oregon State University Press, Corvallis, OR, pp. 106-113.

Cordy, D.R., 1978. Centaurea species and equine nigropallidal encephalomalacia. In: Keeler, R.F., Van Kampen, K.R., James, L.F. (Eds.), Effects of Poisonous Plants on Livestock. Academic Press, New York, pp. 327-336.

DiTomaso, J.M., 2005. Yellow Starthistle Information. <http://wric.ucdavis. edu/yst> (accessed 18.01.06).

DiTomaso, J.M., Kyser, G.B., Orloff, S.B., Enloe, S.F., 2000. Integrated approaches and control option considerations when developing a management strategy for yellow starthistle. California Agriculture 54, 30-36.

Dostál, J., 1976. Centaurea L. In: Tutin, T.G., Heywood, V.H., Burges, N.A., Moore, D.M., Valentine, D.H., Walters, S.M., Webb, D.A. (Eds.), Flora Europaea, vol. 4. Cambridge University Press, Cambridge UK, pp. 254-301.

Duncan, C.L., 2001. Knapweed management: another decade of change. In: Smith, L. (Ed.), Proceedings of the First International Knapweed Symposium of the Twenty-First Century, March 15-16, 2001, Coeur d'Alene, Idaho. USDA-ARS, Albany, CA, pp. 1-7.

Ehret, J.M., 1983. Les Apions de la region Bourgogne. Annales scientifiques de la Société d'Histoire Naturelle et des Amis du Muséum d'Autun. 107, 103-154.

Fisher, A.J., Bruckart, W.L., McMahon, M.B., Luster, D.G., Smith, L., 2006. First report of Puccinia jaceae var. solstitialis pycnia on yellow starthistle in the United States. Plant Disease 90, 1362.

Funk, V.A., Bayer, R.J., Keeley, S., Chan, R., Watson, L., Gemeinholzer, B., Schilling, E., Panero, J.L., Baldwin, B.G., Garcia Jacas, N., Susanna, A., Jansen, R.K., 2005. Everywhere but Antarctica: using a supertree to understand the diversity and distribution of the Compositae. Kongelige Danske Videnskabernes Selskab Biologiske Skrifter 55, 343-374.

Garcia-Jacas, N., Susanna, A., Mozaffarian, V., Ilarsian, R., 2000. The natural delimitation of Centaurea (Asteraceae: Cardueae): ITS sequence analysis of the Centaurea jacea group. Plant Systematics and Evolution $223,185-199$.

Garcia-Jacas, N., Susanna, A., Garnatje, T., Vilatersana, R., 2001. Generic delimitation and phylogeny of the subtribe Centaureinae (Asteraceae): a combined nuclear and chloroplast DNA analysis. Annals of Botany $87,503-515$.

Garcia-Jacas, N., Garnatje, J., Susanna, A., Vilatersana, R., 2002. Tribal and subtribal delimitation and phylogeny of the Cardueae (Asteraceae): a combined nuclear and chloroplast DNA analysis. Molecular Phylogenetics and Evolution 22, 51-64.

Gerlach J.D., 1997a. How the west was lost: reconstructing the invasion dynamics of yellow starthistle and other plant invaders of western rangelands and natural areas. In: Kelly, M., Wagner, E., Warner, P. (Eds.), Proceedings of the California Exotic Pest Plant Council 3, 67-72.

Gerlach Jr., J.D., 1997b. The introduction, dynamics of geographic range expansion, and ecosystem effects of yellow star-thistle (Centaurea solstitialis). Proceedings of the California Weed Science Society 49, 136141.

Haines, M.L., Syrett, P., Emberson, R.M., Withers, T.M., Fowler, S.V., Worner, S.P., 2004. Ruling out a host-range expansion as the cause of the unpredicted non-target attack on tagasaste (Chamaecytisus proliferus) by Bruchidius villosus. In: Cullen, J.M., Briese, D.T., Kriticos, D.J., Lonsdale, W.M., Morin, L., Scott, J.K. (Eds.), Proceedings of the XI International Symposium on Biological Control of Weeds. CSIRO Entomology, Canberra, Australia, pp. 271-276.

Hellwig, F.H., 2004. Centaureinae (Asteraceae) in the Mediterraneanhistory of ecogeographical radiation. Plant Systematics and Evolution 246, 137-162.

Hitchcock, C.L., Cronquist, A., 1998. Flora of the Pacific Northwest: an illustrated manual. University of Washington Press, Seattle.

Jacob, H.S., Briese, D.T., 2003. Improving the selection, testing and evaluation of weed biological control agents. Proceedings of the CRC for Australian Weed Management Biological Control of Weeds Symposium and Workshop, September 13, 2002, University of Western Australia, Perth. CRC for Australian Weed Management Technical Series no. 7 .

Jetter, K.M., DiTomaso, J.M., Drake, D.J., Klonsky, K.M., Pitcairn, M.J., Sumner, D.A., 2003. Biological control of yellow starthistle. In: Sumner, D.A. (Ed.), Exotic Pests and Diseases: Biology and Economics for Biosecurity. Iowa State University Press, Ames, pp. 121-150.

Joley, D.B., Maddox, D.M., Schoenig, S.E., Mackey, B.E., 2003. Parameters affecting germinability and seed bank dynamics in dimorphic achenes of Centaurea soistitialis in California. Canadian Journal of Botany 81, 993-1007.

Kapeluszny, J., Pawlowski, F., 1978. An attempt to determine the threshold of harmfulness of cornflower (Centaurea cyanus L.) and wild chamomile (Tripleurospermum inodorum L. Schultz-Bip.) in winter wheat crops. Roczniki Nauk Rolniczych, A. 103 (2), 25-33.

Keil, D.J. (Ed.), 1993. Asteraceae. In: Hickman, J.C. (Ed.), The Jepson Manual: Higher Plants of California. University of California Press. Berkeley, California, pp. 174-360.

Keil, D.J., Ochsmann, J., 2006. 24. Centaurea Linnaeus. Flora of North America. Vol. 19, 20 and 21, pp. 52, 57, 58, 67, 83, 84, 96, 171, 172, 176, 177. $<\mathrm{http}: / /$ www.efloras.org/florataxon.aspx?flora_id $=1 \&$ taxon_id $=$ $106012>$ (accessed 14.08.06).

Klisiewicz, J.M., 1986. Susceptibility of yellow starthistle to selected plant pathogens. Plant Disease 70, 295-297.

Klokov, M.B., Sonsovskii, D.I., Tsvelev, N.N., Cherepanov, C.K., 1963. Centaurea. In: Flora URSS. XXVIII. Institutum Botanicum nomine V. Komarovii Academiae Scientiarum URSS. Editio Academiae Scientiarum URSS. Moscow, pp. 370-579.

Lorenzi, H.J., Jeffery, L.S., 1987. Weeds of the United States and Their Control. Van Nostrand Reinhold Company, New York. 
Maddox, D.M., 1981. Introduction, phenology, and density of yellow starthistle in coastal, intercoastal, and central valley situations in California. US Department of Agriculture, Agricultural Research Service, Agricultural Research Results. ARR-W-20, July 1981, USDA-ARS, Oakland, California.

Maddox, D.M., Mayfield, A., Poritz, N.H., 1985. Distribution of yellow starthistle (Centaurea solstitialis) and Russian knapweed (Centaurea repens). Weed Science 33, 315-327.

Ochsmann, J., 2001. On the taxonomy of spotted knapweed (Centaurea stoebe L.). In: Smith, L. (Ed.), Proceedings of the First International Knapweed Symposium of the Twenty-First Century, March 15-16, 2001, Coeur d'Alene, Idaho. United States Department of Agriculture, Agricultural Research Service, Albany, CA, pp. 33-41. <http:// www.sidney.ars.usda.gov/knapweed/images/proceed.pdf>.

Pemberton, R.W., 2000. Predictable risk to native plants in weed biological control. Oecologia 125, 489-494.

Pitcairn, M.J., Woods, D.M., Joley, D.B., Fogle, D.G., Popescu, V., 1999a. Impact of seedling pathogens on yellow starthistle in California. In: Woods, D.M. (Ed.), Biological Control Program Annual Summary, 1998. California Department of Food and Agriculture, Plant Health and Pest Prevention Services, Sacramento, CA, pp. 74-76.

Pitcairn, M.J., Woods, D.M., Van Mantgem, E.F., Wall, R.K., 1999b. Endemic natural enemy fauna of yellow starthistle and purple starthistle in central California. In: Woods, D.M. (Ed.), Biological Control Program Annual Summary, 1998. California Department of Food and Agriculture, Plant Health and Pest Prevention Services, Sacramento, CA, pp. 83-84.

Pitcairn, M.J., Woods, D.M., Joley, D.B., Popescu, V., 2002. Seven-year population buildup and combined impact of biological control insects on yellow starthistle. In: Woods, D.M. (Ed.), Biological Control Program Annual Summary, 2001. California Department of Food and Agriculture, Plant Health and Pest Prevention Services, Sacramento, California, pp. 57-59.

Pitcairn, M.J., Woods, D.M., Popescu, V., 2005. Update on the long-term monitoring of the combined impact of biological control insects on yellow starthistle. In: Woods, D.M. (Ed.), Biological Control Program Annual Summary, 2004. California Department of Food and Agriculture, Plant Health and Pest Prevention Services, Sacramento, California, pp. 27-30.

Pitcairn, M.J., Schoenig, S., Yacoub, R., Gendron, J., 2006. Yellow starthistle continues its spread in California. California Agriculture 60, 83-90.

Rechinger, K.H., 1980. 16. Sect. Mesocentron. In: Rechinger, K.H. (Ed.), Flora Iranica. Akademische Druck, U. Verlagsanstalt, Graz, Austria, 139b, pp. 378-381.

Roché Jr., B.F., 1965. Ecologic studies of yellow star-thistle Centaurea solstitialis L. Ph.D. Thesis, University of Idaho, Moscow.

Rosenthal, S.S., Campobasso, G., Fornasari, L., Sobhian, R., Turner, C.E., 1992. Biological control of Centaurea spp. In: James, L.F., Evans, J.O., Ralphs, M.H., Child, R.D. (Eds.), Noxious Range Weeds. Westview Press, Boulder, Colorado, pp. 292-302. Chap. 29.

Rosenthal, S.S., Davarci, T., Ercis, A., Platts, B., Tait, S., 1994. Turkish herbivores and pathogens associated with some knapweeds (Asteraceae: Centaurea and Acroptilon) that are weeds in the United States. Proceedings of the Entomological Society of Washington 96, 162-175.

Schumacher, A.E., Sheley, R.L., Callihan, R.H., Thill, D.C., 1982. Chemotaxonomic analysis of seed proteins as a means of biotype identification of yellow starthistle. Research Progress Report of the Western Society of Weed Science, 31-32.

Sheley, R.L., Callihan, R.H., Huston, C.H., Thill, D.C., 1983a. Genotypic variation among yellow starthistle populations. Research Progress Report of the Western Society of Weed Science, 53-54.

Sheley, R.L., Zamora, D.L., Huston, C., Callihan, R.H., Thill, D.C., 1983 b. Seed and seedling root growth characteristics of several populations of yellow starthistle. Research Progress Report of the Western Society of Weed Science, 62-63.

Sheley, R.L., Larson, L.L., Jacobs, J.J., 1999. Yellow starthistle. In: Sheley, R.L., Petroff, J.K. (Eds.), Biology and Management of Noxious Rangeland Weeds. Oregon State University Press, Corvallis, Oregon, pp. $408-416$.
Sheppard, A.W., 1999. Which test? A mini review of test usage in host specificity testing. In: Withers, T.M., Barton Browne, L., Stanley, J.(Eds.), Host Specificity Testing in Australasia: Towards Improved Assays for Biological Control. Papers from the Workshop on Introduction of Exotic Biocontrol Agents-Recommendations on Host Specificity Testing Procedures in Australasia, Brisbane, October 1998. Scientific Publishing, Indooroopilly, Queensland, Australia, pp. 60-69.

Sheppard, A.W., van Klinken, R.D., Heard, T.A., 2005. Scientific advances in the analysis of direct risks of weed biological control agents to nontarget plants. Biological Control 35, 215-226.

Skinner, K.M., Smith, L., Rice, P., 2000. Using noxious weed lists to prioritize targets for developing weed management strategies, including biological control programs. Weed Science 48, 640-644.

Smith, L., 2002. New developments in the biological control of invasive weeds. Proceedings of the California Weed Science Society 54, 159-165.

Smith, L., 2004. Prospective New Agents for Biological Control of Yellow Starthistle. Proceedings of the California Weed Science Society. 56, 136-138.

Smith, L., 2006. Risk assessment of Ceratapion basicorne, a rosette weevil of yellow starthistle. In: Hoddle, M.S., Johnson, M.W. (Eds.), Proceedings of the Fifth California Conference on Biological Control, July 25-26, 2006, Riverside, CA, pp. 47-54.

Smith, L., Drew, A.E., 2006. Fecundity, development and behavior of Ceratapion basicorne (Coleoptera: Apionidae), a prospective biological control agent of yellow starthistle. Environmental Entomology 35, 1366-1371.

Smith, L., Hayat, R., Cristofaro, M., Tronci, C., Tozlu, G., Lecce, F., 2006. Assessment of risk of attack to safflower by Ceratapion basicorne (Coleoptera: Apionidae), a prospective biological control agent of Centaurea solstitialis (Asteraceae). Biological Control 36, 337-344.

Snarska, K., 2004. [Monitoring of weed infestation-An ecological factor for weed control in cereals.] Monitoring zachwaszczenia-Czynnikiem ekologicznego ograniczenia liczebnosci chwastow w zbozach. Progress in Plant Protection (Poznan, Poland) 44, 1099-1101.

Sun, M., 1997. Population genetic structure of yellow starthistle (Centaurea solstitialis), a colonizing weed in the western United States. Canadian Journal of Botany 75, 1470-1478.

Susanna, A., Garcia-Jacas, N., Soltis, D.E., Soltis, P.S., 1995. Phylogenetic relationships in tribe Cardueae (Asteraceae) based on ITS sequences. American Journal of Botany 82, 1056-1068.

TAG, 2006. Technical Advisory Group for Biological Control Agents of Weeds. <http://www.aphis.usda.gov/ppq/permits/tag/> (accessed 14.08.06).

Taylor, R.J., 1990. Northwest Weeds: the Ugly and Beautiful Villains of Fields, Gardens, and Roadsides. Mountain Press Publishing, Missoula, Montana.

Tibor, D.P., 2001. California Native Plant Society Invetory of Rare and Endangered Plants of California, sixth ed. CNPS Press, Sacramento.

Turner, C.E., Johnson, J.B., McCaffrey, J.P., 1995. Yellow starthistle. In: Nechols, J.R., Andres, L.A., Beardsley, J.W., Goeden, R.D., Jackson, C.G. (Eds.), Biological Control in the Western United States: Accomplishments and benefits of regional research project W-84, 1964-1989. University of California, Division of Agriculture and Natural Resources, Oakland. Publ. 3361, pp. 270-275.

USDA-APHIS, 1998. Reviewer's manual for the Technical Advisory Group for biological control agents of weeds: guidelines for evaluating the safety of candidate biological control agents. USDA-APHIS-PPQ, Marketing and Regulatory Programs. 03/98-01.

USDA-NRCS, 2006. The PLANTS Database, Version 3.5. National Plant Data Center, Baton Rouge, LA. <http://plants.usda.gov> (accessed 30.08.06).

USFWS, 2005. The endangered species program, US Fish and Wildlife Service. <http://endangered.fws.gov/> (accessed 21.11.05).

Uygur, S., Smith, L., Uygur, F.N., Cristofaro, M., Balciunas, J., 2004. Population densities of yellow starthistle (Centaurea solstitialis) in Turkey. Weed Science 52, 746-753.

Uygur, S., Smith, L., Uygur, F.N., Cristofaro, M., Balciunas, J., 2005. Field assessment in land of origin of host specificity, infestation rate and 
impact of Ceratapion basicorne a prospective biological control agent of yellow starthistle. Biocontrol 50, 525-541.

Voronov, F.P., 1977. Application of 2,4-D butyl ester granules to winter wheat. Zashchita-Rastenii 4, 26.

Wagenitz, G., 1955. Pollenmorphologie und Systematik in der Gattung Centaurea L. Flora 142, 213-279.

Wagenitz, G., 1975. 79. Centaurea L. In: Davis, P.H. (Ed.), Flora of Turkey, vol. 5. Edinburgh University Press, Edinburgh, pp. 465-585.

Wagner, H., 1997. Cynareae - Chemical review. In: Heywood, V.H., Harborne, J.B., Turner, B.L. (Eds.), The Biology and Chemistry of the Compositae. Academic Press, London, pp. 1017-1038.

Wanat, M., 1994. Systematics and phylogeny of the tribe Ceratapiini (Coleoptera, Curculionoidea, Apionidae). Genus, International Journal of Invertebrate Taxonomy (Suppl.).

Wapshere, A.J., 1974. A strategy for evaluating the safety of organisms for biological weed control. Annals of Applied Biology 77, 201-211.

Wheeler, G.S., 2005. Maintenance of a narrow host range by Oxyops vitiosa; a biological control agent of Melaleuca quinquenervia. Biochemical Systematics and Ecology 33, 365-383.
Withers, T.M., Barton Browne, L., Stanley, J. (Eds.), 1999. Host specificity testing in Australasia: towards improved assays for biological control. Papers from the Workshop on Introduction of Exotic Biocontrol Agents-Recommendations on Host Specificity Testing Procedures in Australasia, Brisbane, October 1998. Scientific Publishing, Indooroopilly, Queensland, Australia.

Woods, D.M., Pitcairn, M.J., Joley, D.B., 2000. Sequential impacts of endemic pathogens, exotic mollusks, and insects on yellow starthistle (Centaurea solstitialis L.) in California. In: Spencer, N.R. (Ed.), Proceedings of the X International Symposium on Biological Control of Weeds. Bozeman, Montana, USA, 4-14 July 1999, United States Department of Agriculture, Agricultural Research Service, Sidney, MT, and Montana State University-Bozeman, Bozeman, MT, pp. 807-813.

Woods, D.M., Bruckart, W.L., Popescu, V., Pitcairn, M.J., 2004. First field release of Puccinia jaceae var. solstitialis, a natural enemy of yellow starthistle. In: Woods, D.M. (Ed.), Biological Control Program Annual Summary, 2003. California Department of Food and Agriculture, Plant Health and Pest Prevention Services, Sacramento, California, p. 31. 